\title{
Approaches to rehabilitation of radioactive contaminated territories
}

\author{
Anna V Voronina, Vladimir S Semenishchev, ${ }^{*}$ Alexey A Bykov, Marina 0 \\ Savchenko, Andrey S. Kutergin and Tatjana A Nedobuh
}

\begin{abstract}
BACKGROUND: Accidents at nuclear fuel cycle plants may lead to contamination of areas of land and water. Cheap and available sorbents including natural aluminosilicates can be used for rehabilitation and decontamination of large volumes of radioactively contaminated water, including drinking water, prevention of migration of radionuclides into ground and surface waters through the soil and returning contaminated soil to farming.

RESULTS AND DISCUSSION: A comparative study of sorption properties of various natural and surface-modified aluminosilicates with respect to caesium is made. It is shown that sorption features of surface-modified aluminosilicates for Cs were improved by 100-1000 times compared with respective natural aluminosilicates. It is shown that surface modification of glauconite by a mixed nickel-potassium ferrocyanide phase allows it to considerably increase its specificity (caesium distribution coefficients $(2.9 \pm 0.8) \times 10^{3} \mathrm{~mL} \mathrm{~g}^{-1}$ for natural and $(4.5 \pm 0.5) \times 10^{5} \mathrm{~mL} \mathrm{~g}^{-1}$ for modified glauconite) as well as making it selective to caesium in the presence of other alkaline ions and also provides irreversible caesium sorption.

CONCLUSIONS: Due to improved features, modified aluminosilicates can be more successful than natural ones when used for rehabilitation of radioactive contaminated territories (including agriculture) and water areas, as well as for decontamination of liquid radioactive wastes and for creation of geochemical barriers in solid radioactive waste storage.
\end{abstract}

(C) 2013 Society of Chemical Industry

Keywords: aluminosilicates; nickel - potassium ferrocyanide; rehabilitation of radioactive contaminated territories

\section{INTRODUCTION}

Accidents at nuclear fuel cycle plants lead to contamination of areas of land and water. In cases of serious accidents, International Nuclear and Radiological Event Scale levels 5-7, long-living radionuclides such as ${ }^{137} \mathrm{Cs}$ and ${ }^{134} \mathrm{Cs}$ make a major contribution to such contamination. Thus, large areas in Japan were radioactively contaminated as a result of the Fukushima incident. The density of pollution in the most contaminated territories is up to $25-30$ $\mathrm{kBq}$ per $\mathrm{kg}$ of soil (represented by ${ }^{137} \mathrm{Cs}$ and ${ }^{134} \mathrm{Cs}$ ). A map of area contamination by ${ }^{137} \mathrm{Cs}$ and ${ }^{134} \mathrm{Cs}$ in Japan after the Fukushima incident is presented in Fig. 1. The high population density in Japan, the absence of free land and the impossibility of massive resettlement opportunities determine the necessity for rehabilitation of the land and returning the soils to the farming industry.

The principle of differentiated use of land must be the basis of returning contaminated areas to the farming industry. Using various rehabilitation activities depends on the density of pollution, and the efficiency of such activities is to be determined experimentally.

In cases of very high density pollution (specific activity $>2 \mathrm{Ci}$ $\mathrm{km}^{-2}$ ) ploughing of contaminated soil to horizons, unavailable for roots of plants, can be an effective method of rehabilitation. The main results of scientific research and development of agronomical methods that allow the decrease of contamination of farming production grown on radioactive contaminated soils within the territory of East-Urals Radioactive Track, have been described. ${ }^{1}$
The process of decreasing radionuclide migration into plants was the displacement of the contaminated layer of soil to a subsurface layer at a depth of $80-100 \mathrm{~cm}$ without destroying the structure of soil and decreasing its fertility.

By liquidation of consequences of Mayak disaster in 1957 on the lands of East-Urals Radioactive Track with density of pollution < $0.2 \mathrm{Ci}\left({ }^{90} \mathrm{Sr}\right) / \mathrm{km}^{2}$ no restrictions of farming activities were imposed. It was advised to grow forage for beef cattle on land with a density of pollution $0.2-2 \mathrm{Ci} \mathrm{km}^{-2}$ and to grow bread-corn as seeds on land with a density of pollution at $2-8 \mathrm{Ci} \mathrm{km}^{-2}$.

Migration of radionuclides from soil to vegetation occurs through groundwater, therefore methods of retaining radionuclides in soils by the addition of sorption materials to soils can be effective for rehabilitation of areas with the aim of returning contaminated land to farming. Cheap and available sorption materials with good affinity to natural systems are needed for such rehabilitation. Natural aluminosilicates satisfy these requirements; interest and their intensive study are determined by their ion exchange properties and also by the availability of proven deposits in many countries. Natural aluminosilicates and some of their modified

\footnotetext{
Correspondence to: Vladimir S Semenishchev, Ural Federal University, Radiochemistry and Applied Ecology Chair 620002, Mira str. 19, Ekaterinburg
} city, Russia.Email:vovius82@mail.ru

Radiochemistry and Applied Ecology Chair 620002, Ural Federal University, Mira str. 19, Ekaterinburg city, Russia 
文部科学省及び栃木県による航空機モニタリングの結果

（文部科学省がこれまでに測定してきた範囲及び栃木県南部

におけるセシウム134、137の萻積量の合計）

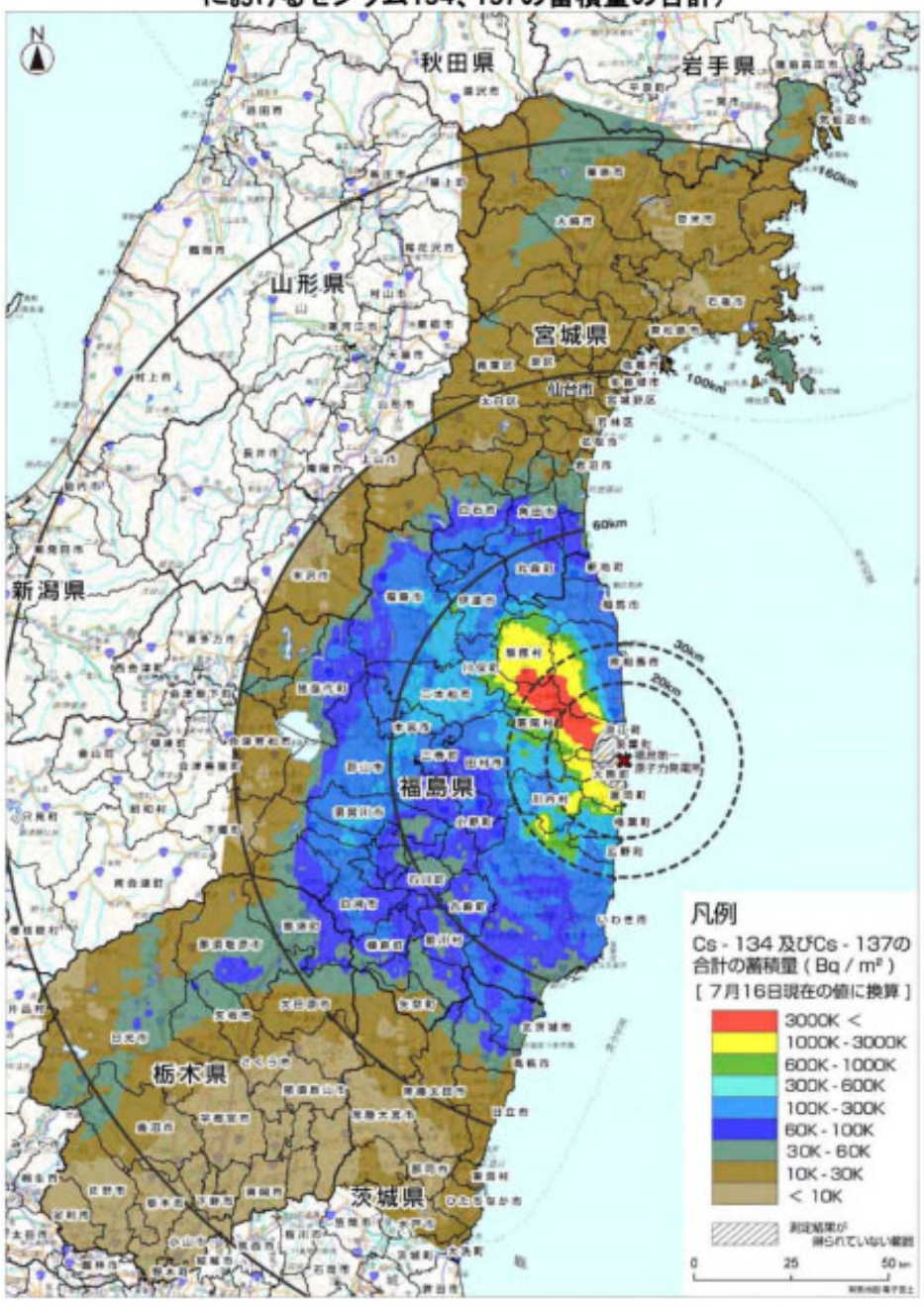

Figure 1. Map of areas contamination by ${ }^{137} \mathrm{Cs}$ and ${ }^{134} \mathrm{Cs}$ in Japan as a result of the Fukushima incident.

\begin{tabular}{|c|c|c|c|}
\hline \multirow[b]{2}{*}{ lons } & \multicolumn{3}{|c|}{ Concentration, $\mathrm{mg} \mathrm{L}^{-1}$} \\
\hline & Rain water & Tap water & Mineral wate \\
\hline $\mathrm{pH}$ & $5.8 \pm 0.2$ & $8.2 \pm 0.2$ & $7.2 \pm 0.2$ \\
\hline $\mathrm{K}^{+}$ & 3.7 & 3.6 & \\
\hline $\mathrm{Na}^{+}$ & 5.0 & 25.5 & $400-900$ \\
\hline $\mathrm{Ca}^{2+}$ & 6.1 & 40.0 & $<50$ \\
\hline $\mathrm{Mg}^{2+}$ & 0.3 & 8.0 & $<25$ \\
\hline $\mathrm{Fe}$ & - & 1.8 & - \\
\hline $\mathrm{Cl}^{-}$ & 4.6 & 16.5 & $400-1050$ \\
\hline $\mathrm{HCO}_{3}{ }^{-}$ & - & - & $300-600$ \\
\hline $\mathrm{SO}_{4}{ }^{2-}$ & 1.7 & 52.5 & $<75$ \\
\hline $\mathrm{NO}_{3}{ }^{-}$ & 1.6 & - & - \\
\hline
\end{tabular}

products have been successfully used for decontamination of radioactive polluted natural waters and technological solutions, liquid radioactive wastes, ${ }^{2-14}$ and remediation of land under high anthropogenic impact. ${ }^{15-20}$
If high caesium specific activity is present in natural water a high decontamination factor will be required; in the case of soil contamination high retention efficiency of radionuclides will be required to prevent their migration into vegetation and further movement through food chains. Therefore, the most important characteristics of sorption materials are specificity, measured as distribution coefficient $K_{d}$, selectivity and irreversibility of sorption. It is possible to increase sorption and mechanical features of natural aluminosilicates by their granulation and/or surface modification. Distribution coefficients of caesium for natural aluminosilicates and some of their modified products described in the abovementioned works do not exceed $10^{3}-10^{4} \mathrm{~mL} \mathrm{~g}^{-1}$ and suggested methods of rehabilitation do not take the behaviour of these sorbents in the environment and the reversibility of radionuclide sorption into account.

It is possible to improve sorption and mechanical features of natural aluminosilicates and make caesium sorption irreversible via surface modification of these aluminosilicates with ferrocyanides.

A comparative study of caesium sorption by clinoptilolites from Shivyrtooysky (Chita region, Russia) and Dzegvi (Georgia) deposits, quartz-glauconite concentrate from Karinskoye deposit (Russia), zeolite from Sibai deposit (Bashkortostan, Russia), vermiculite 
Table 2. Chemical composition (\%wt) of aluminosilicates studied. Relative errors $<10 \%$

\begin{tabular}{|c|c|c|c|c|c|c|c|c|c|c|}
\hline Aluminosilicate & $\mathrm{SiO}_{2}$ & $\mathrm{Al}_{2} \mathrm{O}_{3}$ & $\mathrm{Fe}_{2} \mathrm{O}_{3}$ & $\mathrm{FeO}$ & $\mathrm{MgO}$ & $\mathrm{MnO}$ & $\mathrm{CaO}$ & $\mathrm{TiO}_{2}$ & $\mathrm{Na}_{2} \mathrm{O}$ & $\mathrm{K}_{2} \mathrm{O}$ \\
\hline $\begin{array}{l}\text { Clinoptilolite; Shivyrtooysky deposit } \\
\text { (Chita region, Russia) }\end{array}$ & 74.5 & 14.89 & 1.49 & 0.34 & 0.62 & 0.40 & 1.08 & 0.19 & 3.02 & 3.34 \\
\hline $\begin{array}{l}\text { Clinoptilolite; Dzegvi deposit } \\
\text { (Georgia) }\end{array}$ & 75.3 & 15.07 & - & - & 0.3 & - & 0.8 & - & 6.4 & 2.1 \\
\hline $\begin{array}{l}\text { Quartz-glauconite concentrate; } \\
\text { Karinskoye deposit (Russia) }\end{array}$ & 71.0 & 6.4 & 18.6 & - & 2.2 & 0.015 & 0.8 & 0.14 & $\sim 0.2$ & - \\
\hline $\begin{array}{l}\text { Zeolite; Sibai deposit } \\
\quad \text { (Bashkortostan, Russia) }\end{array}$ & 64.8 & 11.0 & - & - & - & - & 10.0 & - & 5.6 & 8.5 \\
\hline $\begin{array}{l}\text { Vermiculite; Buldymskoe deposit } \\
\text { (Russia) }\end{array}$ & 46.35 & 15.9 & 6.57 & 2.93 & 24.29 & - & 1.45 & 0.98 & - & 1.61 \\
\hline $\begin{array}{l}\text { Manganese Greensand sorbent } \\
\text { (glauconite sand, USA) }\end{array}$ & 76.0 & 5.5 & 20.0 & & 1.8 & 0.5 & 0.7 & 0.1 & $\sim 2.0$ & - \\
\hline
\end{tabular}

Table 3. Distribution coefficients of caesium for natural and modified aluminosilicates

1. Natural aluminosilicates

Clinoptilolite; Shivyrtooysky deposit (Chita region, Russia)

Clinoptilolite; Dzegvi deposit (Georgia)

Quartz-glauconite concentrate; Karinskoye deposit (Russia)

Zeolite; Sibai deposit (Bashkortostan, Russia)

Vermiculite; Buldymskoe deposit (Russia)

Manganese Greensand sorbent (glauconite sand, USA)

2. Surface-modified aluminosilicates

NPF-clinoptilolite

NPF-glauconite

$$
\begin{gathered}
(6.4 \pm 0.6) \times 10^{3}(1.4 \pm 0.1) \times 10^{4}(3 \text { weeks }) \\
(7.9 \pm 1.6) \times 10^{3}(1.3 \pm 0.1) \times 10^{4} \text { (3 weeks) } \\
(2.9 \pm 0.8) \times 10^{3} \\
(3.1 \pm 0.6) \times 10^{2} \\
(1.2 \pm 0.1) \times 10^{3} \\
(4.0 \pm 0.8) \times 10^{3} \\
\\
(5.0 \pm 4.0) \times 10^{6} \\
(4.5 \pm 0.5) \times 10^{5}
\end{gathered}
$$

(Russia) and manganese greensand (glauconite sand, USA) and also surface-modified sorbents based on glauconite and clinoptilolite is made in this work. The assessment of possibility of use of natural and modified aluminosilicates for rehabilitation of radioactive contaminated territories is made.

\section{EXPERIMENTAL}

Aluminosilicates from various deposits with grain sizes $0.2-0.6 \mathrm{~mm}$ were used for the study. Mixed nickel-potassium ferrocyanides based on glauconite and clinoptilolite were obtained using surface chemical modification. This method includes the steps of chemical activation of natural aluminosilicate, sorption saturation by nickel ions and further treatment by $\mathrm{K}_{4} \mathrm{Fe}(\mathrm{CN})_{6}$ solution. Theory of this method has been described. ${ }^{21,22}$

To study the caesium interphase distribution for natural and modified aluminosilicates, the following parameters were used: tap water spiked by ${ }^{137} \mathrm{Cs}$; volume $(V)=50 \mathrm{~mL}$, sorbent weight $(\mathrm{m})$ $=100 \mathrm{mg}, \mathrm{pH}=7.8 \pm 0.2$. Initial range of caesium concentrations in solution $\left(10^{-7}-1000 \mathrm{mg} \mathrm{L}^{-1}\right)$ were obtained using standard solutions of $\mathrm{CsCl}$. Samples were measured via beta-radiometry using low background alpha-beta-radiometer "UMF-2000" with a semiconductor detector.

Selectivity of natural and surface-modified glauconite with respect to caesium in presence of analog ions $\mathrm{K}^{+}$and $\mathrm{Na}^{+}$ was studied at an initial caesium concentration of $0.01 \mathrm{mg} \mathrm{L}^{-1}$. Experiments were performed under static conditions in water solutions spiked by ${ }^{137} \mathrm{Cs}$; with alkali metal ion solutions obtained using standard solutions of $\mathrm{NaCl}, \mathrm{KCl}, \mathrm{CsCl}$. Duration of phase contact was 1 week.

The chemical stability of the saturated samples was determined using the long-term leaching technique. The sample of sorbent saturated by caesium labelled with radioactive ${ }^{137} \mathrm{Cs}$ was placed in a polyethylene container and filled with leachant. Sampling was made after 1, 3, 7, 10, 14, 21 and 28 days from the beginning of experience. The leachant was transferred to a container for subsequent analysis and the sorbent was washed out using the same leachant, filled with a fresh portion of leachant, closed and left for the next time. The content of caesium in the test was determined via $\gamma$-spectrometry. The leachants used were: rain water representing a natural water with very low salt content; tap water as an analogue of natural water with low salt content and relatively high iron content, and a natural mineral water with sodium hydrocarbonate-chloride mineralization, salinity 1.5 $\mathrm{g} \mathrm{L}^{-1}$. Chemical composition of these leachants is presented in Table 1.

\section{RESULTS}

Chemical composition of natural aluminosilicates, calculated for dry matter, is presented in Table 2.

Exchange capacity of aluminosilicates depends on $\mathrm{Al} / \mathrm{Si}$ ratio and concentration of $\mathrm{Na}^{+}, \mathrm{K}^{+}, \mathrm{Ca}^{2+}, \mathrm{Mg}^{2+}$ ions located in interstices of lattice in a hydrate environment. Greater exchange of $\mathrm{Al}^{3+}$ ions in a mineral by iron or magnesium ions leads to additional compensation of electric charge by cations and therefore to increasing exchange capacity. ${ }^{23}$ Ion exchange features 

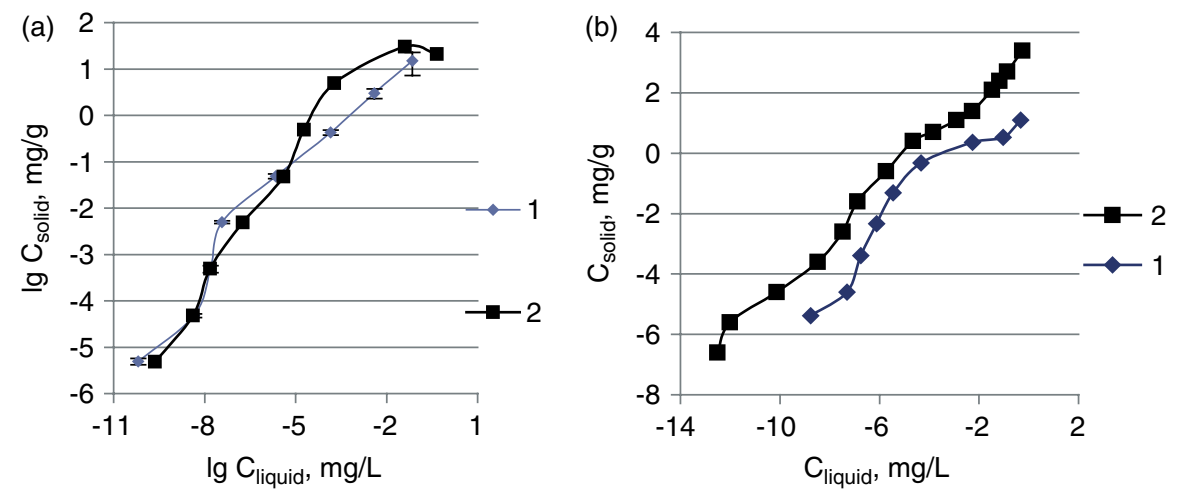

Figure 2. Isotherms of sorption of caesium from tap water: (a) natural aluminosilicates ( 1 = glauconite, Russia; $2=$ clinoptilolite, Russia), (b) surface-modified aluminosilicates ( 1 = based on glauconite (NPF-glauconite); 2 = based on clinoptilolite (NPF- clinoptilolite)).
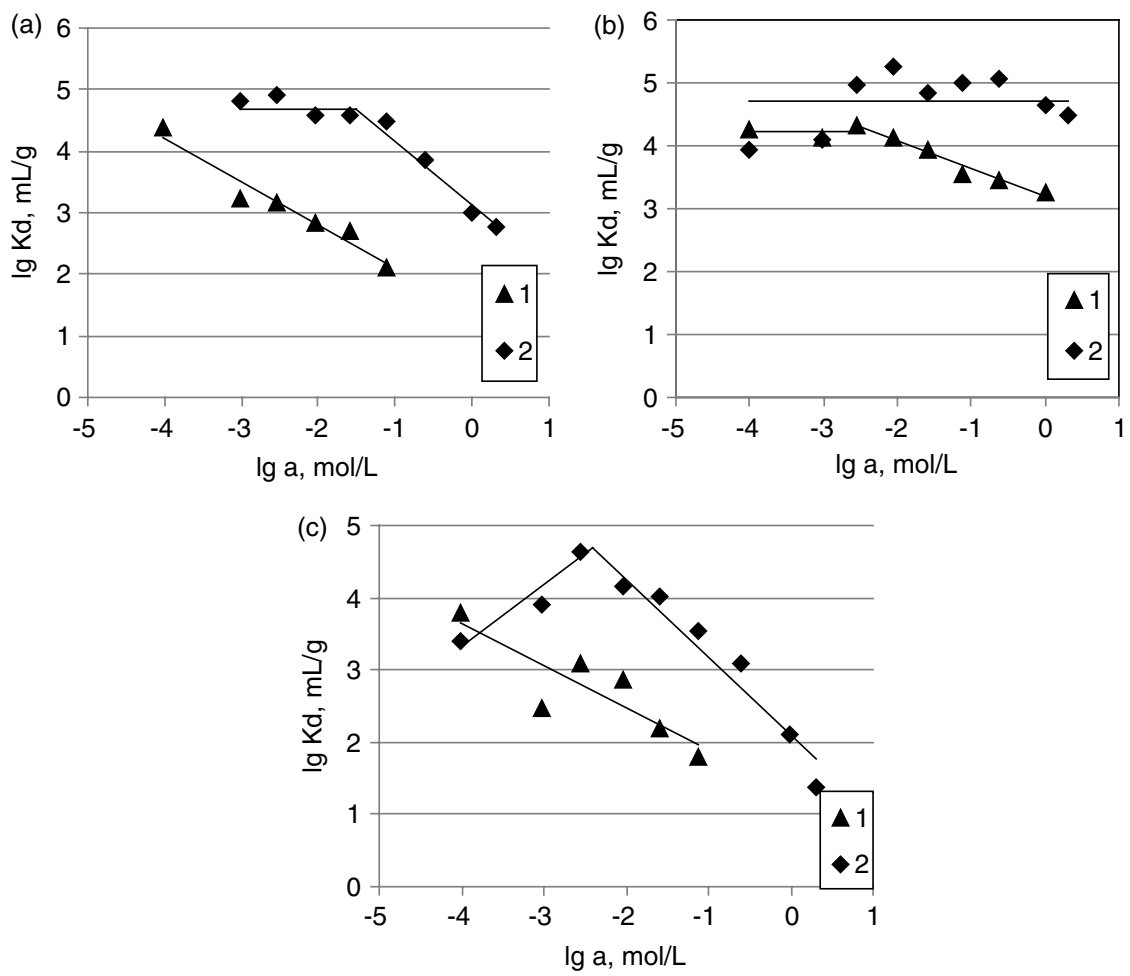

Figure 3. Dependences of caesium distribution coefficients $K_{d}$ on active concentration $a$ of $\mathrm{K}^{+}$(a), $\mathrm{Na}^{+}$(b) and $\mathrm{NH}_{4}^{+}$(c) in solution for natural (1) and surface-modified (2) glauconite.

of aluminosilicates depend on degree of ions replacement, $\mathrm{Al} / \mathrm{Si}$ ratio as well as on peculiarities of interstices and channels and ratios between their sizes and diameters of exchanging ions. Stability of aluminosilicates increases with decrease of $\mathrm{Al} / \mathrm{Si}$ ratio. ${ }^{24}$

Analysis of chemical composition has shown that clinoptilolite and vermiculite possess the most sorption exchange capacity; clinoptilolite possesses higher mechanical strength and chemical stability.

Distribution coefficients of caesium, determined under static conditions and for various durations of saturation, for natural and modified aluminosilicates are presented in Table 3. Data from Table 3 show that various aluminosilicates have various specificities with respect to caesium. The highest distribution coefficients are found for clinoptilolites. It is also obvious, that sorption by these materials can be increased up to $100-1000$ times via surface modification by ferrocyanides. For example, the caesium distribution coefficient for mixed nickel-potassium ferrocyanide on clinoptilolite can reach $(5.0 \pm 4.0) \times 10^{6} \mathrm{~mL} \mathrm{~g}^{-1}$, meanwhile for natural clinoptilolite this coefficient is only $(6.4 \pm 0.6) \times 10^{3} \mathrm{~mL} \mathrm{~g}^{-1}$.

Typical examples of caesium sorption isotherms by natural (a) and surface-modified (b) clinoptilolite and glauconite from tap water (duration of saturation $\tau=1$ week) are presented in Fig. 2 . Isotherms of caesium sorption were made in ' $\lg C_{\text {solid }}-\lg C_{\text {liquid }}$ axes (where $C_{\text {solid }}$ is concentration of caesium in sorbent, $\mathrm{mg} \mathrm{g}^{-1}$ and $C_{\text {liquid }}$ is concentration of caesium in solution, $\mathrm{mg} \mathrm{L}^{-1}$ ) and described by the Langmuir isotherm. Direct proportion between concentration of caesium in sorbent and solution is observed at a certain concentration range for samples of natural glauconite and clinoptilolite as well as for NPF-glauconite.

Zones of linearity of isotherms coincide for natural and modified glauconite. The isotherm of caesium sorption by NPF-clinoptilolite is a three-stage curve. Slopes of each straight-line portion of this 

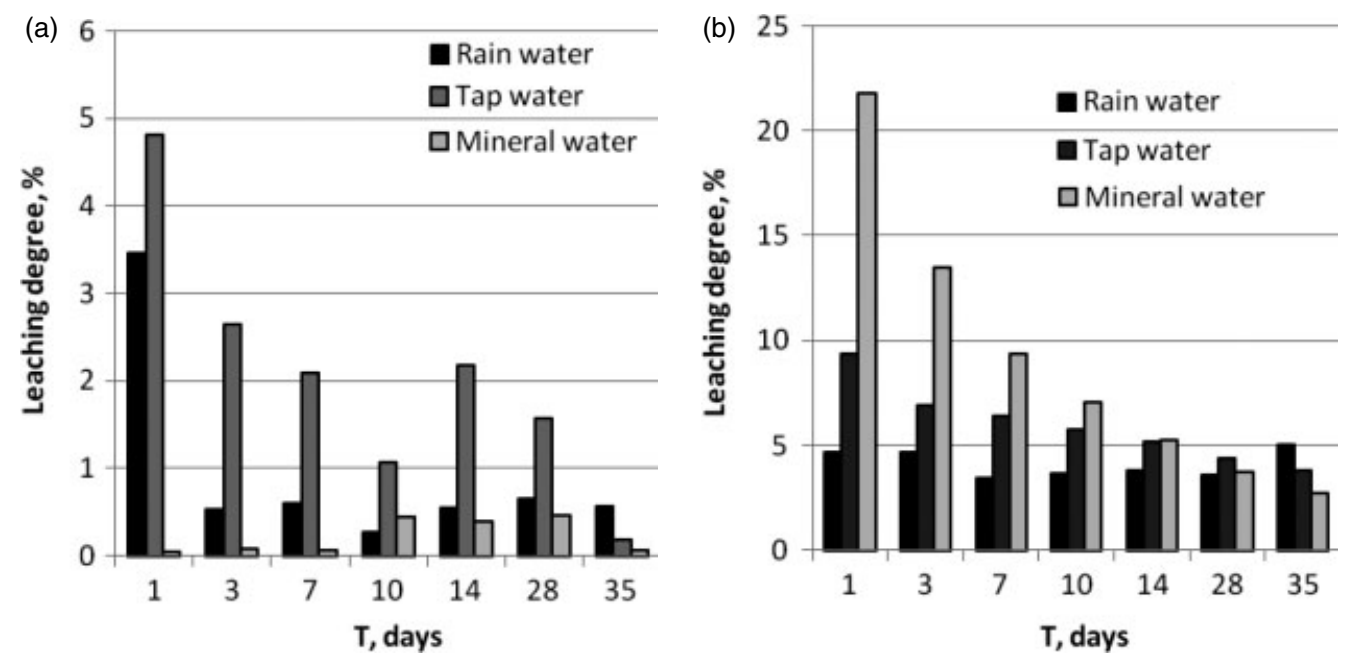

Figure 4. Time dependency of leaching of ${ }^{137} \mathrm{Cs}$ by various leachants from surface-modified glauconite (a) and natural glauconite (b).

curve are equal to 1 within limits of error, i.e. evidence of fulfillment of Henry's law. The form of the isotherm shows that this sorbent has three types of sorption sites and filling of each sorption site can be described by the Langmuir isotherm. The first type of sorption site with $\lg K_{\mathrm{d}}=(7.4 \pm 1.3)$ is realized at caesium concentrations $1 \times 10^{-7}-10^{-5} \mathrm{mg} \mathrm{L}^{-1}$, the second with $\lg K_{\mathrm{d}}=(5.1 \pm 0.3)$ is realized at $1 \times 10^{-4}-1 \mathrm{mg} \mathrm{L}^{-1}$, and the third with $\lg K_{\mathrm{d}}=(3.5 \pm 0.2)$ at $10-1000 \mathrm{mg} \mathrm{L}^{-1}$. Static exchange capacity of NPF-clinoptilolite is $500 \mathrm{mg}$ of Cs per $\mathrm{g}$ of sorbent. A few points in the first linear portion of the isotherm give a large error in the calculated $K_{d}$, however, the $K_{\mathrm{d}}$ is not less than $10^{6} \mathrm{~mL} \mathrm{~g}^{-1}$. The caesium concentration range at which the most specific sorption site is realized corresponds to the normal concentration range of caesium in natural waters, usually within $10^{-9}-10^{-7} \mathrm{~g} \mathrm{~L}^{-125}$ which is important for application of the sorbent.

Dependences of caesium distribution coefficients $K_{d}$ on active concentration $a$ of $\mathrm{K}^{+}$(a), $\mathrm{Na}^{+}$(b) and $\mathrm{NH}_{4}^{+}$(c) in solution for natural and surface-modified glauconite are presented in Fig. 3.

Experimental data show that natural glauconite does not possess caesium selectivity so interference of sodium becomes apparent at concentrations of $0.01 \mathrm{~mol} \mathrm{~L}^{-1}$ and higher, whereas potassium shows some interference over all the concentration range. The interference of sodium with sorption of caesium by surface-modified glauconite is almost absent, allowing more efficient use of this material for separation of ${ }^{137} \mathrm{Cs}$ from natural waters, because sodium is one of main cations, together with calcium and magnesium in all natural waters. In contrast to sodium, potassium shows interference with sorption of caesium by surface-modified glauconite at concentrations of $0.03-0.1$ $\mathrm{mol} \mathrm{L}^{-1}$ and higher, though distribution coefficients of caesium on modifed glauconite remain considerably higher than those on natural glauconite. However, potassium is usually present in natural waters at lower concentrations than sodium with the average potassium concentration up to $0.01 \mathrm{~mol} \mathrm{~L}^{-1}$ in sea-water and rather lower (100-1000 times) in fresh and ground waters, ${ }^{26}$ therefore in real situations potassium will show interference with caesium sorption only when natural aluminosilicates are used.

Ammonium ions show the strongest interference with sorption of caesium by both natural and surface-modified glauconite. $\mathrm{NH}_{4}{ }^{+}$ ions decrease sorption of caesium by natural glauconite over all studied concentration ranges, and their interference with sorption by surface-modified glauconite is absent at concentrations less than $0.003 \mathrm{~mol} \mathrm{~L}^{-1}$. Usually, ammonium ions are present in soils at low concentrations, but ammonia salts are often used as fertilizers. Therefore it is recommended to use nitrate fertilizers instead of ammonia salts, if surface-modified or especially natural aluminosilicates are used for rehabilitation of contaminated agricultural lands.

The degree of leaching of the radionuclide from samples saturated by this radionuclide allows an indirect conclusion about the reversibility of caesium sorption by natural and surfacemodified glauconite to be drawn. The results of leaching of ${ }^{137} \mathrm{Cs}$ by various leachants from saturated samples are presented in Fig. 4.

The results obtained show, that high caesium leaching rates and degrees are typical for natural glauconite irrespective of leachant salinity. Total degree of leaching after 35 days was: mineral water $=63.4 \%$, tap water $=41.6 \%$ and rain water $=28.8 \%$. Thus, it could be expected that there will be no reliable retention of caesium by the solid phase after addition of the natural aluminosilicates into soil. In contrast to natural glauconite, the modified glauconite shows rather better results with the total degrees of leaching under the same conditions: mineral water $=1.5 \%$, tap water $=14.6 \%$ and rain water $=6.6 \%$. Therefore ferrocyanide surface modified glauconite can be used for rehabilitation of land contaminated by radiocaesium.

\section{DISCUSSION AND CONCLUSIONS}

Migration of radionuclides from soil to vegetation occurs through ground water therefore addition of sorbents to soils that are able to reliably sorb caesium and decrease its content in ground water is the only technically feasible way to prevent caesium migration into vegetation. Experiments have shown that modified aluminosilicates will be rather more efficient than natural materials for rehabilitation of radioactive contaminated land and returning the soils to farming. Thus, surface modification of glauconite by a mixed nickel-potassium ferrocyanide phase allows it to considerably increase its specificity as well as making it selective to caesium in the presence of other alkaline ions and also provide irreversible caesium sorption. The only drawback to using modified glauconite for rehabilitating contaminated agricultural land will be some limitation on the amount of inorganic potassium and ammonium fertilizers being used. 
Currently the modified glauconite produced by the authors is being tested at radioactively contaminated areas near Fukushima in Japan. The first results are expected in the autumn of 2013.

As well as the above, modified aluminosilicates can be successfully used for decontamination of large volumes of radioactively contaminated natural water including drinking water, low- and middle-level liquid radioactive wastes as well as the creation of geochemical barriers in solid radioactive waste storage and limiting the migration of radioactively contaminated waters into the lithosphere.

\section{ACKNOWLEDGEMENT}

This study was supported by The Ministry of Education and Science of the Russian Federation, project 14.A18.21.0313.

\section{REFERENCES}

1 Teplyakov IG, Romanov GN and Spirin DA, Returning of lands of EastUrals Radioactive Track to farming. Questions Radiat Safety 3:33-41 (1997).

2 Tsitsishvili GV and Andronikashvili TG, Natural Zeolites. Chemistry, Moscow, 224 (1985).

3 Milyutin VV, Gelis VM and Penzin RA, Sorption-selectivity features of inorganic sorbents and ion exchange resins with respect to strontium and caesium. Radiochemistry 3:76-82 (1993).

4 Bogdanovich NG, Konovalov EB, Starkov OV, Kochetkova EA, Grushicheva EA, Shumskaya VD, Emel'yanov VP and Myshkovskij MP, Sorption extraction of cesium and strontium from liquid radioactive wastes and their immobilization into geocements. Atomic Energy 84:16-20 (1998).

5 Vdovina ED Radyuk RI and Sultanov AS, Use of natural zeolites from Uzbekistan for decontamination of low-level wastewater. Part I. Sorption of radiocaesium. Radiochemistry 3:422-423 (1976).

6 Sultanov AS, Radyuk RI, Tashpulatov D, Vdovina ED, Popova GA and Aripov EA, Decontamination of low-level water from long-lived isotopes using natural sorbents. Radiochemistry 4:667-672 (1976).

7 Sharonov GE and Pogodin RI, About the possibility of treatment of lowlevel radioactive liquid wastes of nuclear plants from caesium-137 by hydrobiotite mineral. Radiochemistry 2:297-299 (1980).

8 Tretyakov SYa, Study of sorption of ${ }^{90} \mathrm{Sr}$ and ${ }^{137} \mathrm{Cs}$ radionuclides by natural sorbents in simulated ecosystems. Radiochemistry 1:89-91 (2002).

9 Rad'ko Al and Panasyugin AS, Sorption of ${ }^{137} \mathrm{Cs}$ and ${ }^{90} \mathrm{Sr}$ by modified sorbents based on clinoptilolite. Radiochemistry 1:66-68 (1996).

10 Chernyavskaya NB, Konstantinovich AA, Andreeva NR, Vorobyeva GE and Skripak IYa, Use of domestic clinoptilolite for decontamination of wastewater from caesium and strontium radionuclides. Radiochemistry 3:441-414 (1983).

11 Tarasevich Yul, Use of natural sorbents as deactivation agents in liquidation of Chernobyl accident aftermath. Chem Technol Water 2:127-131 (1996).
12 Dyer A, Chimedtsogzol A, Campbell L and Williams C, Uptake of caesium and strontium radioisotopes by natural zeolites from Mongolia. Micropor Mesopor Mater 95:72-175 (2006).

13 Kawamura F and Motojima K, Using copper hexacyanoferrate (II) impregnated zeolite for cesium removal from radioactive liquid waste. Nucl Technol 2:242-247 (1982).

14 Borai EH, Harjula R, Malinen L and Paajanen A, Efficient removal of cesium from low-level radioactive liquid wastes using natural and impregnated zeolite minerals. J Hazard Mater 172:416-422 (2009).

15 Bondar' PF, About the assessment of efficiency of sorbents in the capacity of immobilization of radionuclides in soils. Radiat Biol Radioecol 2:267-272 (1998).

16 Pshinko GN and Bogolepov AA, Use of glauconite as a modeling material for study of deactivation of uranium-containing soils. Radiochemistry 1:91-95 (2009).

17 Campbell LS and Davies BE, Experimental investigation of plant uptake of caesium from soils amended with clinoptilolite and calcium carbonate. Plant Soil 189:65-74. (1997).

18 Misaelides $\mathrm{P}$, Application of natural zeolites in environmental remediation: a short review. Micropor Mesopor Mater. 144:15-18. (2011).

19 Budarkov VA, Mayakov EA, Torubarova AA, Kalinin NF, Gelis VM, Milyutin VV and Penzin RA, The method of decreasing of transfer of caesium radionuclides from soil to plants. Russian Federation Patent No. 2013913. 15.06.1994.

20 Ovchinnikov NA and Bezdenezhnykh VS, Method of soils remediation. Russian Federation patent No. 2064748. 10.08.1996.

21 Katsnel'son Yu Ya, Sklyarova ES, Likhachev VA, Zelenshchikov GV and Kapustyan AS, Use of natural sorbents from Rostov region deposits with the aim of rehabilitation of areas being under high anthropogenic impact. Radiochemistry 2:111-121 (1983).

22 Voronina AV, Semenishchev VS, Nogovitsyna EV and Betenekov ND, A study of ferrocyanide sorbents on hydrated titanium dioxide support using physicochemical methods. Radiochemistry 1:69-74 (2012).

23 Voronina AV, Betenekov ND, Nogovitsyna EV and Semenishchev VS, Characteristic features of statics and kinetics of caesium sorption with nickel-potassium ferrocyanides based on hydrated titanium and zirconium dioxides. In Proceedings IEX 2008 Recent Advances in Ion Exchange Theory and Practice, ed by Cox M. Society of Chemical Industry, London, 215-221 (2008).

24 Kuznetsov YuV, Shchebetovsky VN and Trusov AG, Fundamentals of Water Decontamination from Radioactive Pollutions. Atomizdat, Moscow, 360 (1974).

25 Tarasevich Yu.I. Natural Sorbents in Water Decontamination Naukova Dumka, Kiev, 206 (1981).

26 Kul'sky LA, Grornovsky IT, Koganovsky AM and Shevchenko MA, Handbook of Characteristics, Analytical Techniques and Decontamination of Water. Naukova Dumka, Kiev, 680 (1980).

27 Dickson AG and Goyet C, Handbook of Methods for the Analysis of the Various Parameters of the Carbon Dioxide System in Sea Water. 2. ORNL/CDIAC-74 (http://cdiac.esd.ornl.gov/ftp/cdiac74/ chapter5.pdf) 